Globish (An English-Indonesian journal for English, Education and Culture)

Vol. 9 No.1 January 2020

P-ISSN: 2301-9913, E-ISSN: 2597-9132

DOI: http://dx.doi.org/10.31000/globish.v7i2

\title{
The Use Of Self Assessment In Teaching Writing Process
}

\author{
Abdul Rohim \\ English education study programTeacher training and education Faculty \\ Muhammadiyah University of Tangerang \\ abdulrohim2013@yahoo.com
}

The objective of this research is to give information and clear explanation about the use of self assessment in teaching writing process. This research uses the descriptive qualitative research. The population of this research is all students of fifth semester for english study program in Muhammadiyah University of Tangerang.semester academic 2019/2020 consisting of four parallel classes namely class $5 \mathrm{a} 1,5 \mathrm{a} 2,5 \mathrm{a} 3$, and $4 \mathrm{~b} 1$. Based on the research finding, it can be concluded that self assessment is effective in teaching writing self-assessment in writing learning (writing) aims to encourage students to reflect themselves on students' writing abilities. Self-assessment encourages students to think about the purpose of why students learn to write, and to know what and how they learn. And for the teacher should implement it in their class and it still needs further research in order to develop scientific references.

Key words: Self Assessment, Writing,Writing Process.

\section{INTRODUCTION}

Nowadays, our life looks more advanced than before. This progress happened in the field of education as well. There have been many changes and advancements in the field of education, and this has led to increase the demands that must be met for the development of education in Indonesia.

In the past, students have always been demanded to get good grades, but in the past few years the demands have continued to increase, and one of the demands is that students are expected to be active students. What is meant by active students is students directly involved in the learning process.

But what is still often found now is students are still passive, they prefer to be quiet and accept everything that the teacher explains. They look like they are reluctant to ask because they are ashamed or because they don't know what they really don't understand from the material.

Another example of a situation is passive students because they do not know what their shortcomings are and they do not know what to develop, to know this, students are very dependent on the response from the teacher, not from the student's own awareness.

One solution that can be taken to make students active is to do self-assessment in the learning process. University and colleges are the institutions where the students are taught many skills, they are listening, reading, speaking and writing. Out of many skills that the students need in the university, writing is most important. Writing is not only the words which you write on the piece of paper, but also the effective communication of complex ideas in the simplest form of words that every layman can understand. That is why it is the most important skill the students need in university life.

According to description above, the reseacher is interested to know how self assessment activity can help the students of fifth semester for english study program in Muhammadiyah 
P-ISSN: 2301-9913, E-ISSN: 2597-9132

DOI: http://dx.doi.org/10.31000/globish.v7i2

University of Tangerang to identify the mistakes they make when writing in writing process the writing.

\section{THEORITICAL REVIEW}

\section{a. Writing}

Writing takes a time. That's why writing is often referred to as a process. Richards and Miller (2008) "Writing process is recursive, that is, it is a cyclical, overlapping process where the writer may return to earlier stages, or proceed to later stages at any time, or the writer may try several strategies at once" (p.65).

Writing is very helpful for students to make the difference between writing to study and writing to write. Writing is very important as a tool or practice to help students practice and work with the language they have learned. It means that, when the first students to write it very helpful in practice the language and writing them in order to develop the idea of the students' knowledge in thinking. It can also make students distinguish between writing to study and writing for other things as needed.

\section{b. Self Assessment}

Self- assessment belongs to the alternative assessment. It is a kind of assessment that consists of any method of finding out what a student knows or can do that is intended to show growth and inform instruction, and is an alternative to traditional forms of testing, namely multiple choice tests (O'Malley and Pierce, 1996).

Self-assessment is a kind of assessment in which students monitor their own learning. By providing learners with the skills needed to independently monitor their learning, teachers enable them to takegreater responsibility for their learning. Students can be given opportunities to listen to good and poor performance and asked to describe characteristics of good performance. Self-assessment can be a part of portfolio in which students are asked to reflect on a specific performance or on language development over time. The primary foundation of selfassessment is the students' learning autonomy, and this is considered as the key to successful learning. The ability to set one's own goals both within and beyond the structure of a classroom curriculum, to pursue them without the presence of external prod, and to independently monitor that pursuit are all keys to success. Developing intrinsic motivation that comes from a self-propelled desire to excel is at the top of the list of successful acquisition of any set of skills (Brown, 2004: 270)

According to Goodrich (1996) the conditions that must be in place in order for students to receive the full benefits of self-assessment include:

1. An understanding of the value of self-assessment,

2. Access to explicit criteria on which to base the assessment,

3. A particular task or performance to assess,

4. Models of good self-assessment,

5. Direct instruction in and assistance with self-assessment,

6. Cues for appropriate times to self-assess,

7. Opportunities to revise and improve the task or performance, and

8. Practice

Black et al, (2003) suggest the following guidelines for successful implementation of student self-assessment: 
P-ISSN: 2301-9913, E-ISSN: 2597-9132

DOI: http://dx.doi.org/10.31000/globish.v7i2

1. The criteria for evaluating any learning achievements must be made transparent to students to enable them to have a clear overview both of the aims of their work and of what it means to complete it successfully.

2. Students should be taught the habits and skills of collaboration in self-feedback, both because these are the intrinsic values and because self-assessment can help the students to develop the objectivity of their skills.

3. Students should be encouraged to bear in mind the aims of their work and to assess their own progress to meet these aims as they proceed.

In short, self-assessment in writing learning (writing) aims to encourage students to reflect themselves on students' writing abilities. Self-assessment encourages students to think about the purpose of why students learn to write, and to know what and how they learn. There are four ways that can be used by teachers in carrying out self-assessment in writing learning, namely dialogue journals, learning logs, self-assessment of interests and writing awareness and checklists of writing skills (O'Malley and LV Pierce, 2006). Following is an example of the format of a self-assessment sheet in writing skills:

\begin{tabular}{|l|l|l|}
\hline \multicolumn{2}{|c|}{ Self Assessment of Writing Strategies } & \\
\hline Name: & & \\
\hline \multicolumn{1}{|c|}{ Check one box for each statement } & Yes & No \\
\hline Before Writing & & \\
I talked to a friend or partner about the topic & \\
I made a list of ideas on the topic & \\
I made an outline or semantic map & \\
\hline During Writing & \\
I skipped words I didn't know and went back to them later & \\
I substitude a word from my own language & \\
I used drawing or pictures in my writing & \\
\hline After writing & \\
I checked to see if the writing met my purposes & \\
I reread to see if it made sense & \\
I added information or took out information & \\
I edited for spelling, punctuation, capitals and grammar & \\
\hline
\end{tabular}

Self Assessment of Writing Strategies. (O’Malley and Valdez Pierce, 2006, hal. 157).

\section{RESEARCH METHODOLOGY}

This research uses the descriptive qualitative research. It means that the qualitative descriptive approach to give a clear explanation about research process without any interpetative data depth. As mention by Sandelowski (2000) in qualitative descriptive studies, researchers do not need penetrating the data in their deeply interpratation. The population of this research is all students of fourth semester for english study program in Muhammadiyah University of Tangerang.semester academic 2019/2020 consisting of five parallel classes namely class 5a1, 5a2, 5a3, and 5b1. Samples are taken in one class randomly using techniques cluster random sampling. The instrument used by researcher is questionnaires and analyzed them based on the indicators of self assessment of writing strategies. 
P-ISSN: 2301-9913, E-ISSN: 2597-9132

DOI: http://dx.doi.org/10.31000/globish.v7i2

\section{RESEARCH FINDING AND DISCUSSION}

Students in this research were given questionnaires to analyze their work in writing process. After determining the sample through cluster random sampling of research populations, then $5 \mathrm{a} 3$ is determined to be research sample consisting of 20 student. Then the reseacher used questionnaires and analyzed them based on the indicators of self assessment of writing strategies as presented in the following table:

Table 1: Students questionnaires based on the indicators of self assessment of writing strategies

\begin{tabular}{|c|c|c|c|c|c|c|c|c|c|c|c|c|}
\hline \multirow[t]{2}{*}{ Students } & \multicolumn{3}{|c|}{ Before Writing } & \multicolumn{3}{|c|}{ During Writing } & \multicolumn{4}{|c|}{ After Writing } & \multirow[t]{2}{*}{ Yes } & \multirow[t]{2}{*}{ No } \\
\hline & 1 & 2 & 3 & 4 & 5 & 6 & 7 & 8 & 9 & 10 & & \\
\hline 1 & $\sqrt{ }$ & $\mathrm{X}$ & $\sqrt{ }$ & $\sqrt{ }$ & $\sqrt{ }$ & $\mathrm{X}$ & $\mathrm{X}$ & $\sqrt{ }$ & $\sqrt{ }$ & $\sqrt{ }$ & 7 & 3 \\
\hline 2 & $\sqrt{ }$ & $\sqrt{ }$ & $\sqrt{ }$ & $\mathrm{X}$ & $\sqrt{ }$ & $\sqrt{ }$ & $\sqrt{ }$ & $\sqrt{ }$ & $\mathrm{X}$ & $\sqrt{ }$ & 8 & 2 \\
\hline 3 & $\mathrm{X}$ & $\sqrt{ }$ & $\sqrt{ }$ & $\sqrt{ }$ & $\mathrm{X}$ & $\sqrt{ }$ & $\mathrm{X}$ & $\sqrt{ }$ & $\sqrt{ }$ & $\mathrm{X}$ & 6 & 4 \\
\hline 4 & $\sqrt{ }$ & $\sqrt{ }$ & $\sqrt{ }$ & $\mathrm{X}$ & $\sqrt{ }$ & $\sqrt{ }$ & $\sqrt{ }$ & $X$ & $\sqrt{ }$ & $\sqrt{ }$ & 8 & 2 \\
\hline 5 & $\sqrt{ }$ & $\sqrt{ }$ & $\mathrm{X}$ & $\sqrt{ }$ & $\sqrt{ }$ & $\sqrt{ }$ & $\mathrm{X}$ & $\sqrt{ }$ & $\sqrt{ }$ & $\mathrm{X}$ & 7 & 3 \\
\hline 6 & $\mathrm{X}$ & $\mathrm{X}$ & $\sqrt{ }$ & $\sqrt{ }$ & $\sqrt{ }$ & $\mathrm{X}$ & $\sqrt{ }$ & $\sqrt{ }$ & $\mathrm{X}$ & $\mathrm{X}$ & 5 & 5 \\
\hline 7 & $\mathrm{X}$ & $\mathrm{X}$ & $\mathrm{X}$ & $\sqrt{ }$ & $\sqrt{ }$ & $\sqrt{ }$ & $\mathrm{X}$ & $\sqrt{ }$ & $\sqrt{ }$ & $\sqrt{ }$ & 6 & 4 \\
\hline$\sqrt{ }$ & $\sqrt{ }$ & $\sqrt{ }$ & $\mathrm{X}$ & $\sqrt{ }$ & $\sqrt{ }$ & $\sqrt{ }$ & $\sqrt{ }$ & $\mathrm{X}$ & $\sqrt{ }$ & $\mathrm{X}$ & 6 & 4 \\
\hline 9 & $\mathrm{X}$ & $\mathrm{X}$ & $\sqrt{ }$ & $\sqrt{ }$ & $\sqrt{ }$ & $\mathrm{X}$ & $\sqrt{ }$ & $\sqrt{ }$ & $\sqrt{ }$ & $\sqrt{ }$ & 7 & 3 \\
\hline 10 & $\sqrt{ }$ & $\sqrt{ }$ & $\sqrt{ }$ & $\mathrm{X}$ & $\sqrt{ }$ & $\sqrt{ }$ & $\mathrm{X}$ & $\mathrm{X}$ & $\mathrm{X}$ & $\mathrm{X}$ & 5 & 5 \\
\hline 11 & $\mathrm{X}$ & $\mathrm{X}$ & $\sqrt{ }$ & $\sqrt{ }$ & $\vec{V}$ & $\mathrm{X}$ & $\sqrt{ }$ & $\sqrt{ }$ & $\sqrt{ }$ & $\mathrm{X}$ & 6 & 4 \\
\hline 12 & $X$ & $\sqrt{ }$ & $\sqrt{ }$ & $\sqrt{ }$ & $\mathrm{X}$ & $\sqrt{ }$ & $\sqrt{ }$ & $\sqrt{ }$ & $\sqrt{ }$ & $\mathrm{X}$ & 7 & 3 \\
\hline 13 & $\mathrm{X}$ & $\sqrt{ }$ & $\sqrt{ }$ & $\sqrt{ }$ & $\mathrm{X}$ & $\sqrt{ }$ & $\sqrt{ }$ & $\sqrt{ }$ & $\sqrt{ }$ & $\mathrm{X}$ & 8 & 2 \\
\hline 14 & $\sqrt{ }$ & $\sqrt{ }$ & $\sqrt{ }$ & $X$ & $\sqrt{ }$ & $\sqrt{ }$ & $\sqrt{ }$ & $X$ & $X$ & $\mathrm{X}$ & 6 & 4 \\
\hline 15 & $\mathrm{X}$ & $\sqrt{ }$ & $\sqrt{ }$ & $\sqrt{ }$ & $\mathrm{X}$ & $\sqrt{ }$ & $\sqrt{ }$ & $\sqrt{ }$ & $\sqrt{ }$ & $\mathrm{X}$ & 7 & 3 \\
\hline 16 & $\mathrm{X}$ & $\sqrt{ }$ & $\sqrt{ }$ & $\sqrt{ }$ & $\sqrt{ }$ & $\sqrt{ }$ & $\sqrt{ }$ & $\mathrm{X}$ & $\sqrt{ }$ & $\mathrm{X}$ & 7 & 3 \\
\hline 17 & $\sqrt{ }$ & $\sqrt{ }$ & $\sqrt{ }$ & $\sqrt{ }$ & $\mathrm{X}$ & $\sqrt{ }$ & $\sqrt{ }$ & $\sqrt{ }$ & $\sqrt{ }$ & $\mathrm{X}$ & 8 & 2 \\
\hline 18 & $X$ & $\mathrm{X}$ & $\sqrt{ }$ & $\sqrt{ }$ & $\sqrt{ }$ & $X$ & $\sqrt{ }$ & $\sqrt{ }$ & $\mathrm{X}$ & $\mathrm{X}$ & 5 & 5 \\
\hline 19 & $\mathrm{X}$ & $\sqrt{ }$ & $\sqrt{ }$ & $\sqrt{ }$ & $\mathrm{X}$ & $\sqrt{ }$ & $\mathrm{X}$ & $\sqrt{ }$ & $\sqrt{ }$ & $\mathrm{X}$ & 7 & 3 \\
\hline 20 & $\mathrm{X}$ & $\sqrt{ }$ & $\sqrt{ }$ & $\sqrt{ }$ & $\mathrm{X}$ & $\sqrt{ }$ & $\sqrt{ }$ & $\sqrt{ }$ & $\sqrt{ }$ & $\mathrm{X}$ & 7 & 3 \\
\hline
\end{tabular}

Note : $\quad \sqrt{\text { as a }}$ "yes"

$\mathrm{X}$ as a "no"

The results of the questionnaires showed that most students who were given questionnaires about writing essay using self assessment of writing strategies answered almost "yes" on their questionnaires rather than "no". It means that this indicated positive attitudes towards the implementation of self-assessment in this context. I believed that the self-assessment practice could help them identify the mistakes they make when writing.

Students can recognize and check their writing performance in self assessment activity. Self assessment is very effective because it can promote learning by helping students become more accurate judges of the quality of their workself-assessment learners can recognize their problems and strong point and work on them and the student s' language learning can be controlled, they have chances to give feedback to their own work and evaluate their procedure for learning, and it can also present them criteria to evaluate their work. 
P-ISSN: 2301-9913, E-ISSN: 2597-9132

DOI: http://dx.doi.org/10.31000/globish.v7i2

\section{CONCLUSION}

Self assessment that the students did become very important, not only for understanding their skills in writing but also for helping them identify the mistakes they make when writing.. This research showed that the fifth semester students in english study program at Muhammadiyah University of Tangerang are able to recognize and check their writing performance in self assessment activity. Based on the questionnaires given which indicated positive attitudes towards the implementation of self-assessment in this context. I believed that the self-assessment practice could help them identify the mistakes they make when writing. And i recommend that the teacher can implement it their class and it still need further research in order to develop scientific references.

\section{References}

Black, P., Harrison, C., Lee, C., Marshall, B., \& Wiliam D. (2003). Assessment for Learning: Putting it into Practice. Berkshire: Open University Press..

Brown, H. Douglas. 2004. Language Assessment, Principles and Classroom Practices. New York:

Goodrich, H. (1996). Student self-assessment: At the intersection of metacognition and authentic assessment. Unpublished doctoral dissertation. Cambridge, MA: Harvard University

O'Malley, J. Michael and Pierce, Lorraine Valdes. 1996. Authentic Assessment for Language Learners, Practical Approaches for Teachers. Longman: AddisonWesley Publishing Company.

Richards, J., Miller, S. (2008). Doing Academic Writing in Education: Connecting the Personal and the Professional. Taylor \& Francus e-Library

Sandelowski,M. (2000). Whatever happened to qualitative description? Research in nurshing and health, 23. 